DOI: https://doi.org/10.32839/2304-5809/2021-6-94-18

УДК 342.97

Шарапова О.В., Зленко О.О.

Національний науковий центр

«Інститут судових експертиз ім. Засл. проф. М.С. Бокаріуса»

\title{
РОЗВИТОК ЕЛЕКТРОННОГО ДОКУМЕНТООБІГУ В СПОЛУЧЕНИХ ШТАТАХ АМЕРИКИ
}

\begin{abstract}
Анотація. У даній роботі розглядаються особливості впровадження системи електронного документообігу в США та становлення і подальшого реформування законодавчої бази США, що регулює електронний документообіг, як частину електронного урядування. В основу процесу трансформації відносин між державою та суспільством було налагоджено інформаційно-комунікаційних технологій 3 метою створення нових організаційних і економічних структур, розвиток орієнтованих на споживача підходів у наданні державних послуг. Розглянуто сучасний етап розвитку електронного документообігу як основну складову державного управління електронного урядування. Реалізація концепції електронного уряду підвищує ефрективність роботи державного апарату, сприяє розвитку економіки, а також створює передумови для формування нової моделі демократії - цифрової демократії.
\end{abstract}

Ключові слова: документообіг, електронні системи документообіг, розподіл та обробка інформації, управління організацією, створення, обробка та зберігання інформації.

Sharapova Olena, Zlenko Oleksandr National Scientific Centre «Hon. Prof. M.S. Bokarius Forencic Science Institute»

\section{DEVELOPMENT OF ELECTRONIC DOCUMENT FLOW IN THE UNITED STATES OF AMERICA}

Summary. This paper examines the features of the introduction of electronic document management in the United States and the formation and further reform of the US legal framework governing electronic document management as part of e-government. The process of transformation of relations between the state and society was based on information and communication technologies in order to create new organizational and economic structures, the development of consumer-oriented approaches in the provision of public services. Transformation represents the evolution of e-government of the highest order. Initiatives of this level involve the use of the full potential of technology to transform citizens' perceptions of public administration functions, their organization and implementation. Such initiatives will build on the strong customer relationship management capacity needed to address the full range of issues, problems and needs. Currently, there are not many examples of this type of initiative, which is partly due to administrative, technical and fiscal constraints. The current stage of development of electronic document management as the main component of public administration of e-government is considered. The following reasons are put forward as a substantiation of necessity and importance of realization of the concept of electronic document circulation: transparency of activity of state institutions for citizens of the country and foreigners; increasing the efficiency and effectiveness of management decisions; reducing the cost of maintaining the state apparatus and increasing the productivity of civil servants; fight against corruption in government structures, etc. The implementation of the concept of e-government increases the efficiency of the state apparatus, promotes economic development, and creates the preconditions for the formation of a new model of democracy - digital democracy. The desire of modern society to automate, open information raises questions about the security of data use. In this regard, it is especially important to protect data from unauthorized use. Information security should be one of the leading factors in the development of e-government concepts.

Keywords: document flow, electronic document management systems, distribution and processing of information, organization management, creation, processing and storage of information.

$\Pi$ остановка проблеми. Концепція електронного документообігу виникла як результат двох тенденцій кінця XX століття широкомасштабного реформування державного управління в цілях підвищення його едективності та розвитку інформаційно-комунікаційних технологій.

У 1970-80 рр. ХХ ст. багато країн зіткнулися 3 низкою проблем, пов'язаних $з$ роботою органів державного і муніципального управління: великими фрінансовими витратами, неефективними процесами в галузі управління, незадовільними результатами політики державної та муніципальної влади.

У деяких країнах витрати на діяльність державних установ стали необгрунтовано високими або зростали занадто швидкими темпами. Найбільшу стурбованість стали викликати випадки втрат, затримок, поганого управління і корупщії в державному секторі. Все це призводило до неефрективного перетворення державних грошей в послуги державних установ. Зокрема, рішення, які брали державні службовці, часто виявлялися досить далекими від потреб громадськості, від джерел інформації та реальному житті. Державні чиновники абсолютно не несли відповідальності за свої рішення та дії перед тими, на кого вони впливали. У ряді країн державний сектор виявився нездатним забезпечити те, що він покликаний був забезпечити: від зовнішньої і внутрішньої безпеки до підтримки сільського господарства, освіти, охорони здоров'я, соціальних послуг тощо.

Процес реформування державного управління почав стрімко розгортатися в світі 3 1980-х рр. Виклики часу, 3 якими зіткнулися держави 
в кінщі XX століття, стали причиною перегляду традиційних моделей і методів державного управління в багатьох країнах. На перший план виходить проблема визначення принципів демократії вимогам ефрективності, відкритості, відповідальності.

Реформи органів і систем управління включали скорочення чисельність державного апарату, зменшення кількості внутрішніх нормативних документів, впровадження в практику державних установ стандартів якісного обслуговування клієнтів [1]. Державним установам, зокрема, пропонувалося уточнити категорії своїх "клієнтів» і вивчити їх потреби, розробити стратегії підвищення якості послуг, а також критерії та механізми оцінки якості обслуговування.

Аналіз останніх досліджень та публікацій. Питання пов'язані 3 провадженням документообігу всебічно досліджуються науковцями, про що свідчать чисельні публікації в періодичних виданнях та виданнях науково-практичної літератури. Серед них можна виділити таких авторів, як М. Круз, В Макаренко, О. Шкурат, В. Степанова, А. Савельева та ін.

Метою статті $є$ аналіз особливостей впровадження електронного документообігу в установах та організаціях Сполучених Штатів Америки. Процес становлення та редрормування систем електронного документообігу, як реалізації програми електронного урядування США.

Виклад основного матеріалу дослідження. У середині 1990-х рр. в США почався новий етап редорм електронного документообігу, пов'язаний з розвитком та масовим поширенням інформаційно-комунікаційних технологій [2] Будучи найбільшим споживачем індрормації, 3 одного боку, і самим значним постачальником послуг, з іншого боку, держава не могла залишатися за рамками процесів інфрорматизації. В основу процесу трансдормації відносин між державою та суспільством було налагоджено інформаційно-комунікаційних технологій з метою створення нових організаційних і економічних структур, розвиток орієнтованих на споживача підходів у наданні державних послу.

Інформаційні технології дозволяють:

- керувати всіма видами урядової інформації, яка сама по собі є стратегічним ресурсом;

- обробляти і адмініструвати дані, з тим щоб їх було зручно використовувати;

- забезпечувати поширення та багаторазове використання інформації (хоч він був один раз введеної в систему, інформація використовується багатьма людьми і багаторазово);

- ефрективно обмінюватися інформацією в електронному вигляді (одного разу введена інформація може зберігатися і пересилатися без додаткової трудомісткої ручної роботи);

- захищати інформацію;

- зберігати інформацію;

- підтримувати і постійно вдосконалювати систему роботи з індрормацією.

Так почалося формування концепції електронного документообігу. Таким чином, розвиток сучасного суспільства та сукупність явищ, що відбуваються в ньому, е умови для виникнення френомена «електронного документообігу» та його стрімкого розвитку.
3 середини 1990-х рр. в мережі Інтернет починає з'являтися урядова інформація, відзначається швидке зростання кількості урядових веб-сайтів. Відбувається інтеграція всіх основних індрормаційних систем і ресурсів органів державної влади, що дозволяе на цій базі організувати ефективну мережеву взаємодію з зовнішнім середовищем, включаючи громадян і організації. Ранне впровадження технологій електронного документообігу було характерно для країн США [3], Великобританії, Сінгапуру, Австралії, Нової Зеландії.

32000 р уряди країн-лідерів розпочали розробки національних програм розвитку електронних державних послуг. Можна говорити про новий етап розвитку електронного документообігу, що узагальнював сукупність проектів різних рівнів влади в галузі інформатизащії.

У березні 1999 року уряд США опублікував стратегію своєї модернізації, яка передбачала переведення всіх державних послуг в електронний формат до 2008 р. Після цього цілий ряд інших держав почав розробку проектів електронного документообігу: UK Online в Свропі, Singapore ONE в Азіі. Широке використання універсальних систем електронного документообігу, створених на етапі реалізації масштабних проектів електронного уряду, виявилося обмеженим та недостатнім рівнем організації роботи всередині урядових структур.

Відносини між державою та суспільством змінювалися за допомогою використання інформаційно-комунікаційних технологій 3 метою створення нових організаційних і економічних структур, оптимізації процесів всередині урядових підрозділів, розвитку орієнтованих на споживача підходів у наданні державних послуг.

Сучасний етап розвитку електронного документообігу можна розглядати як основну складову державного управління електронного урядування.

Реалізація концепції «електронного документообігу» підрозділяеться на кілька етапів.

Джедррі В. Зейорерт пропонує схему для класифрікації етапів еволюції проектів електронного документообігу, що базуеться на ступені розвитку інформаційних технологій, які використовуються для електронної доставки послуг. Виділяється чотири стадії еволюції електронних послуг: присутність, взаємодія, трансакція і трансформація. Автор зазначає, що певна ініціатива в рамках електронного уряду необов'язково повинна починатися 3 першого етапу і проходити послідовно через усі стадії. Навпаки, в проекті створення можуть бути опущені деякі рівні або з самого початку, або вже в міру здійснення проекту.

Присутність - перший етап розвитку. Присутність є простим і найменш дорогий доступ до електронного уряду, який, однак, дає найменше число варіантів для громадян. Типовим прикладом $е$ базовий веб-сайт, в якому "побіжно» перераховуеться інформація про заснування, така як час його роботи, поштова адреса та/або номери телефонів, проте без будь-якого інтерактивного потенціалу. Це пасивне уявлення загальної інформації. Деякі дослідники називають сайти такого типу «брошурної частиною» комп'ютера, даючи тим самим зрозуміти, що мова йде про електронний еквіваленті брошури, надруковані на папері. 
Другий етап - це взаємодія. Хоча інтерактивні елементи на базі веб-сайту створюють ширші можливості, зусилля в рамках ціеї групи як і раніше обмежуються здатністю здійснювати функції впорядкування та автоматизації державного управління. Варіанти взаемодії відносно прості i, як правило, «обертаються» навколо надання інформації. Цей ступінь розвитку електронного уряду допомагае споживачеві уникнути поїздки в будь яку установу або телефонних дзвінків, оскільки робить зазвичай запитувану інформацію та повідомлення доступними у будь-який час доби.

Третім етапом в еволюції ініціатив електронного уряду е трансакція. Ці ініціативи носять більш складний характер, ніж просто надання інформації і уособлюють типи діяльності, які в свідомості населення асоціюються 3 електронним урядом. Вони дозволяють кліентам виконувати повні обсяги завдань в електронному вигляді в будь-який час дня і ночі. Ці ініціативи по суті справи дозволяють створювати свого роду операції «самообслуговування» щодо таких завдань, як продовження ліцензії, оплата податків і зборів та подача пропозицій за закупівельними контрактами. Хоча рівень інтерактивності тут більш широкого масштабу, ніж в «ініціативах» другого етапу, ці види діяльності, як і раніше передбачають наявність потоку інформації в основному 3 одностороннім рухом (або в напрямку органів державного управління, або в напрямку клієнта, в залежності від характеру діяльності).

Трансформація представляе собою еволюцію електронного уряду найвищого порядку. Ініщіативи даного рівня припускають використання всього потенціалу технології для трансформації сприйняття громадянами функцій державного управління, їх організації та виконання. Такі ініщіативи будуть спиратися на міцний потенщіал управління відносинами з кліентом, необхідні для вирішення всього спектру питань, проблем і потреб. В даний час існуе не так багато прикладів цього типу ініщіатив, що частково викликано адміністративними, технічними і фріскальними обмеженнями. Однією з відмінностей цих ініціатив є те, що вони сприяють безперешкодному потоку інформації та процесу прийняття рішень на основі співпраці між владою різного рівня. Іншими словами, «трансформатівних» ініціативи електронного уряду прагнуть до прийняття рішень в інтересах кліента. Деякі прихильники такого підходу висловлюють думку про те, що на самому передовому рівні електронний уряд потенщійно здатний реорганізувати, скомбінувати та/або ліквідувати існуючі установи та замінити їх віртуальними організаціями.

Д. Мун в своїй статті висувае п'ятирівневий варіант:

1. Формування присутності держави в мережі Інтернет: з'явилась можливість звернення до органів державної влади через інтернет-зв'язок.

3. Інтерактивна присутність держави: в електронній формі здійснюеться обмін інформаціею між громадянами та органами державної влади.

4. Присутність держави мережі Інтернет на рівні трансакцій: користувачі мають змогу здійснювати он-лайн послуги (сплата податків, сплата реестраційного збору та митних зборів).

5. Повністю інтегрована присутність держави мережі Інтернет: завершена повна інтегращія дер- жавних інтернет-ресурсів в рамках единого порталу (створення електронних единих реєстрів) [4].

Для переходу на новий щабель розвитку електронного документообігу необхідно вирішити ряд проблем, а саме: фрінансове та технічне забезпечення, інформаційна грамотність населення, цифровий розрив між окремими категоріями громадян. Також важливу роль відіграє розвиток електронного урядування у кожному федеральному окрузі окремо: їх взаємодія на місцевому рівні (горизонтальні зв'язки) і співробітництво з федеральним урядом (вертикальні зв'язки).

Джефрфррі В. Зейферт пропонуе схему для класифрікації етапів еволющії проектів електронного документообігу, що базуеться на ступені розвитку інформаційних технологій, які використовуються для електронної доставки послуг. Виділяеться чотири стадії еволюції електронного локументування: присутність, взаємодія, трансакщія і трансформація. Автор зазначае, що певна ініціатива в рамках електронного уряду необов'язково повинна починатися 3 першого етапу і проходити послідовно через всі стадії [5]. Навпаки, в проекті створення можуть бути опущені деякі рівні або з самого початку, або вже в міру здійснення проекту.

Присутність - перший етап розвитку. Присутність $є$ простим і найменш дорогий доступ до електронного документообігу, який, однак, дає найменше число варіантів для громадян. Типовим прикладом є базова система документообігу, в якій «побіжно» перераховуеться інформація про заснування, така як годинник його роботи, поштова адреса та/або номери телефонів, проте без будь-якого інтерактивного потенціалу.

Другий етап - це взаємодія. Хоча інтерактивні елементи на базі системи електронного документообігу створюють ширші можливості, зусилля в рамках ціеї групи як і раніше обмежуються здатністю здійснювати функції впорядкування і автоматизації державного управління. Варіанти взаемодії відносно прості i, як правило, «обертаються» навколо надання інформації. Цей ступінь розвитку електронного документування допомагае споживачеві уникнути поїздки в якусь установу або телефонних дзвінків, оскільки робить зазвичай запитувану інформацію та повідомлення доступними у будь-який час доби. Ці ресурси можуть включати інструкції з отримання послуг, відомості, які можна «витягти», роздрукувати, заповнити і відправити поштою до установи, або ж вказують адресу електронної пошти, щоб відповісти на прості запитання.

Третім етапом в еволюції ініціатив електронного документообігу е трансакція. Ці ініціативи носять більш складний характер, ніж просто надання інформації і уособлюють типи діяльності, які в свідомості населення асоціюються з електронним документуванням. Вони дозволяють кліентам виконувати повні обсяги завдань в електронному вигляді в будь-який час дня і ночі. Відповіді в електронній формі, як правило, однотипні і породжують передбачувані результати (наприклад, продовження ліцензій, створення письмового підтвердження внесення вами пропозищії на торгах тощо.

Трансформація представляе собою еволюцію електронного документообігу найвищого 
порядку. Ініціативи даного рівня припускають використання всього потенщіалу технології для трансформації сприйняття громадянами фрункцій державного управління, їх організації та виконання. Такі ініщіативи будуть спиратися на міцний потенціал управління відносинами 3 клієнтом, необхідний для вирішення всього спектру питань, проблем і потреб. В даний час існуе не так багато прикладів цього типу ініціатив, що частково викликано адміністративними, технічними і фріскальними обмеженнями.

Електронний уряд має на увазі реалізацію послідовного, простого і індивідуалізованого підходу в наданні послуг та інформації для населення [6]. Це означае структурну перебудову фрункціонування державних організацій і їх взаємодії з громадянами, приватними компаніями і власними службовцями.

Можна сказати, що реалізація концепції електронного уряду підвищуе едективність роботи державного апарату, сприяє розвитку економіки, а також створює передумови для фрормування нової моделі демократії - цифрової демократії (digital democracy), заснованої на можливості прямої участі громадян у вирішенні державних питань шляхом онлайн-голосування, при більш повному підпорядкуванні діяльності уряду суспільству. 3 іншого боку, кожна країна має свої особливості розвитку держави, існуючі традиції, внутрішньо-і зовнішньополітичну ситуацію. Це означає, що при розробці концепцій повинні враховуватися ці особливості.

Також, якщо говорити про глобальне процесі індорматизації суспільства і розвитку інформаційних технологій, існують як позитивні, так і негативні моменти. Прагнення сучасного суспільства до автоматизації, відкритості інформації ставить питання про безпеку використання даних (наприклад, персональної і особистої інформації). В цьому відношенні особливо важливо стає забезпечити захист даних від несанк- ціонованого використання. Безпека інфрормації повинна займати одне з провідних місць при розробки концепцій електронного уряду.

Висновки і пропозиції. Сполучені Штати Америки є таким собі «локомотивом» 3 впровадження діджиталізації в країні. На сьогоднішній день практично всі громадяни країни - це, по суті кажучи, величезний медіаресурс, що володіє великим потенціалом для проведення державної пропаганди. Зі створенням єдиного урядового порталу в рамках електронного уряду держава отримуе в свої руки засіб для інформаційного забезпечення своеї діяльності, засіб для впливу на громадську думку.

Особливе місце в концепції електронного уряду займає можливість прямого звернення до всіх державних чиновників через інтернет. Для цього існуе кілька основних способів. Найбільш поширені 3 них - це надання публічної адреси електронної пошти або створення на сайті відомства спеціальної форми для відправки повідомлення в державну установу. За допомогою подібної форми або по електронній пошті будь-який громадянин може написати будь-які побажання і зауваження щодо діяльності конкретного відомства, а також задати його питання. При цьому передбачається, що відповідь буде дана або по електронній пошті, або викладений на відомчому сайті в спеціальній рубриці «відповіді».

Однак, якщо говорити про глобальні процеси інформатизації суспільства і розвитку інформаційних технологій, існують як позитивні, так і негативні моменти. Прагнення сучасного суспільства до автоматизації, відкритості інформації ставить питання про безпеку використання даних (наприклад, персональної та особистої інформації). У цьому відношенні особливо важливо стає забезпечити захист даних від несанкціонованого використання. Безпека інформації повинна займати одне з провідних місць при розробки концепцій електронного уряду.

\section{Список літератури:}

1. Голобуцкий О.П., Шевчук О.Б. Електронний уряд. Київ : ЗАТ «Атлант UMS», 2002.174 с.

2. The E-Government Act of 2002. URL: http://frwebgate.access.gpo.gov/cgibin/getdoc.cgi?dbname=107_cong_ public_laws\&docid=f:publ347.107.pdf

3. Andy Brack, Phil Noble. E-Democracy around the World: A Survey for the Bertelsmann Foundation, Summer, 2001. P. 1.

4. Moon M.J. The evolution of e-government among municipalities: Rhetoric or reality. Public Administration Review. 2002. № 4. P. 425-427.

5. Зейферт Джеффри В. Руководство по компьютеризации функций государственного управления: секторы, этапы, возможности и вызовы управления в режиме реального времени. URL: http://www.infousa.ru/ information/rl31057.htm

6. Кузнецов С.Л. Електронний уряд - що це таке? Адміністративне право. 2010. № 1. С. 103-110.

\section{References:}

1. Golobutsky O.P., Shevchuk O.B. (2002) E-government. Kyiv: CJSC "Atlant UMS", 174 p.

2. The E-Government Act of 2002. URL: http://frwebgate.access.gpo.gov/cgibin/getdoc.cgi?dbname=107_cong_ public_laws\&docid=f:publ347.107.pdf

3. Andy Brack, Phil Noble. E-Democracy around the World: A Survey for the Bertelsmann Foundation, Summer, 2001, p. 1.

4. Moon M.J. (2002) The evolution of e-government among municipalities: Rhetoric or reality. Public Administration Review, no. 4, pp. 425-427.

5. Seifert, Jeffrey W. Guide to computerization of public administration functions: sectors, stages, opportunities and challenges of real-time management. URL: http://www.infousa.ru/information/rl31057.htm

6. Kuznetsov S.L. (2010) E-government - what is it? Administrative Law, no. 1, pp. 103-110. 